\title{
A NEVELÉSTUDOMÁNYI MESTERPROGRAMOK HELYZETE ÉS PROBLÉMÁI
}

\section{ÁTTEKINTÉS A MTA PEDAGÓGIAI BIZOTTSÁGA SZÁMÁRA ${ }^{1}$}

\author{
BREZSNYÁNSZKY LÁSZLó ${ }^{*}-$ M. NÁDASI MÁRIA ${ }^{* *}$ \\ * a Debreceni Tudományegyetem Bölcsészettudományi Karának egyetemi tanára \\ brezs1@tigris.unideb.hu \\ ** az Eötvös Loránd Tudományegyetem Pedagógiai és Pszichológiai Karának \\ egyetemi tanára \\ nadasi.maria@ppk.elte.hu
}

A Bologna folyamat a tudományterületek mindegyikét rákényszerítette arra, hogy a felsőoktatás változó rendszerében megkeresse vagy újrafogalmazza a szakmai utánpótlást biztosító alap- és mesterszakok helyét, céljait, képesítési követelményeit. A neveléstudomány területén ez a munka szakmai bizottság keretében folyt a 20042007 közötti időszakban.

Az MTA Pedagógiai Bizottsága a téma fontosságát elismerve tủzte napirendre a pedagógia szakos képzés, közelebbről a neveléstudományi mesterszak létesítésének és indításának folyamatáról és eredményeiről szóló áttekintést. A Pedagógiai Bizottság 2008. február 15-i ülésére készült összefoglalót kissé frissített változatban ajánljuk a Pedagógusképzés olvasóinak figyelmébe.

\section{A neveléstudományi MA helye a bolognai rendszerben}

A felsőoktatási besorolás ${ }^{2}$ szerint a pedagógia képzési területe: bölcsészettudományi; képzési ága: pedagógia és pszichológia. A képzési ág szerkezetileg „messze esik" a pedagógusképzés képzési területétöl, ahová az óvodapedagógus, tanító és a gyógypedagógus képzési ág került besorolásra, jóllehet a célterületük és a képzés iránt érdeklődők potenciális köre - mind az alapszak (BA), mind a mesterszak (MA) és a doktori képzés esetében - jórészt egybeesik. A megvalósuló képzéseket pedig tartalmi és személyi szempontból hagyományosan erős szálak kötik össze.

\footnotetext{
${ }^{1}$ A Pedagógiai Bizottság kérésére összeállította M. Nádasi Mária és Brezsnyánszky László.

${ }^{2}$ 252/2004. (VIII.30.) Korm. r. A többciklusú, lineáris felsőoktatási képzési szerkezet bevezetésének egyes szabályairól és az első képzési ciklus indításának feltételeiről.
} 
A bolognai rendszer szakmai logikája szerinti a szakterületen egymásra épülő ciklusokat a pedagógia alapszak (BA) $\rightarrow$ a neveléstudományi MA $\rightarrow$ és a neveléstudományi doktori $\mathrm{PhD}$ képzés valósítja meg.

A hazai felsőoktatás-politika az alulról építkezés logikáját követi ennek elönyeivel és hátrányaival együtt. Vagyis a rendszer átalakítása az alapszakokkal kezdődött, ezt követte a mesterszakok kidolgozása, és napjaink aktualitása a doktori iskolák akkreditációja.

\section{Az alapszak létesítése}

A BA követelményrendszerének kidolgozása és a szaklétesítés 2004-2005 során történt meg a HEFOP pályázat keretben, támogatott formában. Munkacsoport alakult a szakindításban érintett felsőoktatási intézmények képviselőinek részvételével. A bizottság elnöke Brezsnyánszky László volt. A munka Hunyady György képzési ágra vonatkozó irányítása mellett folyt. Az intézményi szakindítások 2005-ben kerültek a MAB elé.

Az alapszak tantervének kidolgozásakor a MAB illetékes szakbizottságának ajánlásaiból indultunk ki, vagyis a szak fő tanulmányi területeinek megfelelö törzsképzési tárgyak kerültek viszonylag egyenletes kredit-arányokkal a tantervi hálóba. Ezzel folytonosság valósult meg az ún. kredites képzés (a 2001-es bölcsész tárgyakra vonatkozó) követelményrendszere és az alapképzési szak között. Sikerült elkerülni a korai túlspecializálódást az alapozó és a törzstárgyak körében, illetve azt a más szakok esetében előforduló „megoldást”, amely az alapképzés hat szemeszterébe igyekezett a korábbi rendszer 10 félévének valamennyi tárgyát belesüríteni. Ugyanakkor le kellett mondanunk több újabb tartalmat ígérő speciális vagy határterületi tantárgy beépítéséről. Ezeket az intézményi szakindítás játékterébe utaltuk, illetve a képzés differenciált szakaszában láttunk lehetőséget a sajátos és egyben gyakorlatorientált kollégiumok elhelyezésére. A munkacsoport a differenciált képzés számára három irányt fogalmazott meg: a nevelési asszisztens, az oktatási asszisztens és kutatási asszisztens képzést.

Az áttekintés készítésének időszakában 11 intézmény hirdetett pedagógia BA szakot nappali és levelező formában, ${ }^{3}$ államilag finanszírozott, illetve költségtérítéses helyekre. A meghirdetett helyek irányszáma valamennyi intézmény, képzési hely és képzési forma szerint összesen: 815 fö. A tervezett minimális létszám ugyancsak mindösszesen: 226 fö.

A pedagógia alapszak követelményrendszerében megjelent a mesterképzés előképe. Akkor még meglehetősen formális jelentőséggel, hiszen a második és harmadik bolognai ciklus koncepciója és rendeleti terve nem fogalmazódott meg részleteiben.

\footnotetext{
${ }^{3}$ DE BTK, EKF TKTK, ELTE PPK, KJF, ME BTK, NYF PKK, NYMSE MNSK, PE BTK Pápa, PTE BTK, SZTE BTK, WJLF.
} 


\section{A neveléstudományi mesterszak létesítése}

A mesterszak követelményrendszerének kidolgozása 2005 októberében indult el. Hunyady György, a bölcsészkari dékánok kollégiuma szakági koordinátorának, felkérö levelével Brezsnyánszky László és M. Nádasi Mária kapott társelnöki megbízást arra, hogy szervezze és irányítsa a követelményrendszer megfogalmazását.

Egy feljegyzés és egy előkészületben lévő rendelettervezet állt a rendelkezésünkre a szak életre hívásához. A képzési és kimeneti követelmények (kkk) kidolgozása érdekében újraélesztettük a pedagógia alapszak munkacsoportját. A munkacsoport üléseinek az ELTE PPK biztosított helyet ${ }^{4}$, és innen történt a levelezés koordinálása. A munkálatokba hét felsőoktatási intézmény delegált képviselőket, állandó és változó bizottsági tagokat. Az intézmények alfabetikus sorrendben: DE, EKF, ELTE, NyF, PE, PTE, SzTE. A munkálatokban rendszeresen és személyesen résztvevők névsora: Brezsnyánszky László, Czachesz Erzsébet, Forray Katalin, Kozma Tamás, M. Nádasi Mária, Szabolcs Éva, Szabó László Tamás, Vidákovich Tibor. Csak bizonyos szakaszban vagy online formában kapcsolódtak a munkálatokba: Csíkos Csaba, Falus Iván, Horváth H. Attila, Nagy Mária, Venter György.

A munkacsoport ülésein egy olyan program született konszenzusos alapon, amelynek a legfontosabb alapelvei a következőkben jelölhetők meg:

- az alapszakok szemszögéböl széles befogadó ${ }^{5}$,

- ugyanakkor közös alapokat feltételezö ${ }^{6}$,

- az alapozó és törzsképzésben az alapszak tanulmányi területeit és kompetenciáit továbbépító és mélyítő modulokra épített,

- a kimeneti szakaszban széles szakirány választékot ${ }^{7}$ biztosító,

- a szakirány területén elkészíthető szakdolgozathoz lehetőségeket, feltételeket felajánló.

Az alapelvek érvényesülésétől várható, hogy a neveléstudományi MA a korábbi 10 féléves képzés értékeit továbbviszi, ugyanakkor az alapszakkal és a választott szakiránnyal együtt tartalmában és szakmai fejlesztő lehetőségeiben azt meghaladó képzettséget biztosít, $\mathrm{s}$ ily módon a szakmai tudás és készségek terén megfelelő lehet az utánpótlás biztosítása a neveléstudományi doktori képzés számára.

\footnotetext{
4 A munkacsoport hat, emlékeztetőben is rögzített ülést tartott 2005-2006 során.

5 A kkk-ban szereplö szakok felsorolása: a) a bemenethez feltétel nélkül elfogadott alapszakok: pedagógia alapszak (BA); b) a bementhez megadott feltételekkel elfogadott alapszakok: andragógia, viselkedéselemző, tanító, óvodapedagógus, szociálpedagógia (BA szakok).

${ }^{6}$ A bizottság által javasolt előzmények a felvételhez (kreditek együttesen): Alapozó ismeretek terén: a müvelődés és tudomány területéről; az oktatási, nevelési intézmények, szervezetek világából; az informatika és számítógép-használat (IKT) köréből (4-6 kredit területenként); Neveléselmélet/nevelésfilozófia; Magyar és egyetemes neveléstörténet; Nevelés- és oktatásszociológia; Nevelés- és oktatáslélektan; Kutatásmódszertan (4-6 kr. területenként) Nevelési, oktatási, gyermekjóléti, segítőszolgálati terepgyakorlat (összesen 8-10 kr.)

${ }^{7}$ Felsorolás az 1. sz. mellékletben.
} 
A szak célját és elérendő eredményeit az alábbiakban fogalmaztuk meg: „Olyan szakemberek képzése, akik széles körü, mester szintủ szaktudományos és alkalmazói tudással rendelkeznek a neveléstudomány mủvelése és alkalmazása területén. A képzés során kialakult kompetenciáik alapján képesek a köz- és a felsőoktatásban, illetve az oktatásügyben kutatói és/vagy alkalmazói feladatokat ellátni, részt vállalni a rendszerszintü müködtetés feladataiból, a kutatás és fejlesztés terén feladatokat végezni, hazai és nemzetközi szakmai fórumokon a nevelésügy hazai eredményeit kommunikálni."

A képzés eredményeként elvárt általános és szakmai kompetenciák:

A neveléstudományi mesterképzés végzettséget olyan hallgatók kaphatják, akik:

a) A képzés során ismereteiket illetően bizonyították, hogy a neveléstudományi, ezen belül a neveléstörténeti, nevelésfilozófiai, nevelés- és oktatáslélektani, neveléselméleti, oktatáselméleti, nevelésszociológiai, oktatásügyi komparatisztikai, kutatásmódszertani ismereteket elsajátították, az ezeken a területeken megszerzett tudásokkal felkészültek a neveléstudományi doktori képzésbe való belépésre, illetve a szakképzettségüknek megfelelő munkakörök ellátására;

b) ismereteik alkalmazása és képességeik fejlettsége révén alkalmasak a nevelés- és oktatásügyben, a köz- és felsőoktatásban kutatói és/vagy alkalmazói feladatok ellátására, pedagógiai rendszerek fejlesztésében, müködtetésében és irányításában való részvételre, az ezekkel a feladatokkal kapcsolatos magyar és idegen nyelvü információ feltárására, elemzésére, a nevelés- és oktatásügy eredményeinek hazai és nemzetközi fórumokon való kommunikálására, illetve önálló tanulással meglevő képességeik fejlesztésére és új kompetenciák elsajátítására;

c) a szakmai attitüdök és magatartás terén rendelkeznek a szakképzettségüknek megfelelö munkakörökben való önálló munkavégzés, az alkotás, problémamegoldás és döntés, emellett az együttmüködés, a közösségbe történő beilleszkedés képességével és igényével, tevékenységük kritikus értékelésének és irányításának a képességével, és az önszabályozás, az önfejlesztés igényével, valamint értékek kialakítására és megtartására törekvő céltudatos magatartással.

A bizottság vitáinak jellegzetes pontjai, témái:

- a mesterképzési szak elnevezése,

- az alapozó és törzsképzés szakterületeinek és tantárgyainak rendszere, arányai, tartalmi csomópontjai,

- kreditallokáció,

- a javasolt szakirányok köre és tartalma,

- a belépés kritériumai és az átjárhatóság kérdései (kiváltképpen a pedagógusképzési ágról, ág felé). 
A munkacsoport a MAB szaklétesítési formátumába illesztett dokumentumot ${ }^{8}$ 2006 novemberében adta át a kidolgozásban részt vett intézmények nevében és egyetértésével, a szaklétesítés további ügyeinek intézése érdekében a gesztoráló ELTE PPK-nak.

A szaklétesítés folyamatában ettől a mozzanattól kezdve a fenti konzorciumi bizottság mandátuma lejárt, a mesterszak sorsa a továbbiakban a gesztor belátása és döntései szerint alakult.

A MAB-nak benyújtott anyagot 2006. december 13-án visszakaptuk hiánypótlásra: az aktuális szabályozásnak megfelelően valamennyi önálló képzettségként feltüntetett szakirányt külön-külön be kellett mutatni (kreditszám, képzési és kimeneti követelmények, ismeretanyag részletezés és bemutatás.) Az anyag benyújtáskor ugyanis az akkor érvényes MAB elvárásoknak megfelelően három szakirányt mutatott be ilyen részletességgel az ELTE, bár ennél többet szándékozott indítani. A hiánypótlás során (december utolsó két hetében) sor került a konzorciumban részt vevő intézmények képviselői által valamennyi (összesen 11) szakirány igényelt részletességü bemutatására. A munka szervezése az ELTE-ről, mint gesztor karról történt.

A kiegészített, az ELTE által 2007 januárjában benyújtott dokumentumot a MAB 2007. április 3-án elfogadta, ami a neveléstudományi mesterszak tizenegy szakiránnyal való megalapítását jelentette.

A neveléstudományi mesterszak képzési és kimeneti követelményeinek OKM rendeletben történő kiadása előtt (2007 májusában) azonban a minisztérium részéről az ELTE rektorához intézett kérelem érkezett, amelyben a szakalapítási tervhez kapcsolódóan további információkat kértek, javaslatokat fogalmaztak meg. A központi kérdést a konzorcium is sokszor vitatta: milyen feltételekkel történjék a bemenet, az átmenet a pedagógusképzési ágról, de a kérdések érintették a kompetencia leírásokat is. Többszöri, az ELTE vezetésén keresztül zajló levélváltás eredményeként született meg az OKM észrevételeivel összhangban levő, a 120 kredit volumenủ neveléstudományi MA képzési és kimeneti követelményeinek módosított leírása. (Lásd a mellékletben az ennek alapján megjelenő 15/2006-os, ma is érvényes kormányrendeletet.)

\section{Szakindítások és rendeleti környezetük}

A Pedagógiai Bizottság számára készített beszámoló előtt megkérdeztük a szakindításban érintett intézményeket a munkacsoportban résztvevő kollégák segítségével. Azt kívántuk megtudni, hogy hol és milyen feltételek mellett folyt vagy folyik a szak akkreditációja, milyen szakirányokkal és érdeklődéssel számolnak.

\footnotetext{
${ }^{8}$ A mesterszak tantervi szerkezetét az 1. sz. melléklet tartalmazza.
} 
Külön kívántuk elemezni, hogy a gyorsan változó MAB követelmények milyen hatással voltak, vannak a szak indításának, a képzés megvalósításának és az együttmüködésnek az esélyeire. Közismert ugyanis, hogy a felsőoktatási törvény, illetve a MAB plénum határozatainak módosításai, mindenekelőtt a személyi feltételek biztosítása terén egyre nehezedő „,akadálypályát” hoztak létre a képzés feltételeinek biztosítása számára. Úgy látjuk, hogy ez a körülmény a neveléstudományi szakterületet a pedagógus/tanárképzés és a saját mester- és doktori képzés oldaláról halmozottan érinti.

A beérkezett válaszok és egyéb források alapján felvázolhatjuk a jelenlegi (2008. február), nyilvánvalóan átmeneti helyzetet. Neveléstudományi MA szakindítási engedéllyel rendelkezik: ELTE PPK - nappali és levelező formában, Pannon Egyetem. A MAB-nál szakindítást kezdeményezett: DE BTK Neveléstudományok Intézete. A szakindítási kérelem benyújtására készül (intézményi szinten folynak munkálatok): PTE BTK Neveléstudományi Intézet, SZTE BTK Neveléstudományi Intézet ${ }^{9}$. A neveléstudományi MA szakot első alkalommal az ELTE indította 2007. őszén a kora gyermekkor pedagógiája szakirányon.

Az elnyert vagy készülő szakindítások karon vagy egyetemen belüli együttmüködésre épülnek. Az ennél szélesebb körü kooperációt (pl. a közös képzést) ${ }^{10}$ a MAB követelmények módosításai gyakorlatilag nem teszik lehetővé.

A mesterképzések indításának rendeleti környezete gyorsan változik. A MAB 2007 során részben a felsőoktatási törvény módosításai nyomán, részben saját hatáskörében a mesterképzésre vonatkozó követelményeit többször szigorította, ilyenek pl. a 2007. decemberi módosítások, 2008. február 1-jei hatálybalépéssel ${ }^{11}$. Ebből következően a mesterszak indítását kezdeményezők egy éven belül háromféle követelményrendszerrel számolhattak, attól függően, hogy melyik időszakban készítették a kérelmet. Nyilvánvaló módon az az intézmény járt jobban, amelyik hamarabb lépett, tudott lépni. A szabályozás a szakmailag közeli tanári MA-t hasonló módon érintette.

A legfőbb gond nem a szigorítások tendenciájából adódik, jóllehet a szakterület képzési feladataihoz mért személyi feltételei nem kedvezőek. Sokkal inkább abból, hogy a változások kiszámíthatatlanul, a már futó BA szabályaitól eltérő, illetve következetlenségeket mutató módon történtek. Ilyen gondok jelentkeztek a tantárgy, tanegység, tantárgyfelelős értelmezésénél, az egy oktatóra vonatkozó kreditmennyiség (5 tantárgy?, 25 kredit?, 35 kredit?) meghatározásánál, az oktatók és kutatók foglalkoztatás szempontjából történő besorolásában és hasonló kérdésekben.

\footnotetext{
${ }^{9}$ A kézirat leadásának idejére a sikeres akkreditáció nyomán szakindítási engedéllyel rendelkezik: a DE, a PTE és a SZTE.

${ }^{10}$ Irányelvek a közös képzés véleményezéséhez: MAB 2006/9/VIII. határozat módosítása 2007/7/II. , kiegészítés: 2007/10/IX. sz. határozattal.

11 A MAB 2007/10/V. sz. határozata az alapképzési és mesterképzési szakok indításának akkreditációs követelményeiröl.
} 
Mindez visszahatott a már müködő alapszakok intézményi programjára azzal, hogy a képzési ciklus végigvitele előtt több helyen módosításokra került sor.

A felsőoktatás átalakítása és a szakok új rendszerének, egymásra épülésének kialakítása soktényezős és kemény játszma. Sokféle érdek, szándék és szakmai racionalitás, korábban megoldatlan probléma színezi át az állásfoglalásokat és a döntéseket. A neveléstudományi mesterszak létesítése a konzorciumi bizottság szemszögéből nézve - úgy véljük - felmutatja ennek a sajátos szakmai erőtérnek az aktuális helyzetét és erőviszonyait.

\section{SZ. MeLLÉKLeT \\ A NEVELÉSTUdOMÁNYi MESTERSZAK \\ TANTERVI SZERKEZETE}

A konzorciumi bizottság tervezete: összzesen 120 kredit (4 félév)

Törzsanyag (kötelező ismeretkörök):

I. Elméleti alapozás:

Neveléstörténeti tanulmányok, kutatások

Nevelésfilozófiák és elméletek története 3 kredit

Elméleti pedagógia

A neveléstudomány szaknyelve 2 kredit

Nevelés- és oktatáslélektan

Kognitív pszichológia 3 kredit

Neveléslélektan 3 kredit

Oktatástudomány

Tanítás- és tanuláselméletek 3 kredit

A nevelésszociológia alkalmazásai

A nevelésszociológiai információ 3 kredit

Oktatásügyi komparatisztika

Világgazdasági változások és az oktatás 3 kredit

II. Szakmai törzsanyag:

Neveléstörténeti tanulmányok, kutatások

Pedagógiai problématörténet, történeti antropológia 5 kredit 
Elméleti pedagógia

Neveléselmélet - pedagógiai antropológia

3 kredit

Neveléstudományi modellek és paradigmák

3 kredit

Nevelés- és oktatáslélektan

Pedagógiai szociálpszichológia

2 kredit

Oktatástudomány

Tantervelméletek

3 kredit

Képességek fejlődése és fejlesztése 2 kredit

A nevelésszociológia alkalmazásai

Iskolaszociológiai szemléletek és szakirodalom $\quad 3$ kredit

Kutatások a nevelésszociológiában $\quad 2$ kredit

Oktatásügyi komparatisztika

Oktatási rendszerek az EU-ban 3 kredit

Oktatásstatisztikai elemzések 2 kredit

Összesen 48 kredit

\section{Differenciált szakmai anyag}

Kötelezően választható szakirányú modul / szakirány - amennyiben az létezik: 42 kredit a szakindítást kezdeményező intézmény követelményei szerint.

Szabadon választható ismeretek: Az ide sorolható kollégiumok körét a mesterszak intézményi szakmai gazdája határozza meg és hirdeti ki. A szabadon választható kollégiumok kreditjei az alapozó, a törzsképzés kiegészítéseként, illetve a szakirány kiterjesztéseként egyaránt akkumulálhatók. 10 kredit

Diplomamunka: A szakdolgozat kredit értéke: 20 a szakirány kreditjeihez számolva. Ezt a kreditmennyiséget a hallgató a szakdolgozat készítése során, az ahhoz vezető teljesítményei alapján, illetve a dolgozat benyújtásával akkumulálja.

Szakirányok felsorolása. (önálló szakképzettséget adó szakirányok)

családpedagógiai;

elméleti és történeti kutatások;

felsőoktatás-pedagógiai;

gyermek- és ifjúsági tanulmányok;

intézményfejlesztői;

kora gyermekkori pedagógiák; mérés és értékelés;

multikulturális nevelés;

nevelési és oktatási kutatások;

pedagógiai tervezés és értékelés;

segítő-fejlesztő pedagógiai;

tanterv- és programfejlesztő szakképzettség. 


\section{SZ. MELLÉKLET \\ 15/2006 OM RENDELET}

\section{NEVELÉSTUDOMÁNYI MESTERKÉPZÉSI SZAK}

\section{A mesterképzési szak megnevezése: neveléstudományi}

2. A mesterképzési szakon szerezhető végzettségi szint és a szakképzettség oklevélben szereplö megjelölése:

- végzettségi szint: mesterfokozat (magister, master; rövidítve: MA)

- szakképzettség: okleveles neveléstudomány szakos bölcsész

- a szakképzettség angol nyelvü megjelölése: Master in Education

- választható szakirányok: kora gyermekkor pedagógiája, családpedagógia, elméleti és történeti kutatások, felsőoktatás-pedagógia, gyermek- és ifjúsági tanulmányok, intézményfejlesztés, mérés és értékelés, nevelési és oktatási kutatások, segítő-fejlesztő pedagógia, tanterv- és programfejlesztés, multikulturális nevelés

- szakirányok angol nyelvü megnevezése: early childhood and primary education, family education, history and philosophy of education, higher education, childhood and youth studies, institution development, measurement and evaluation, research in education, development and support in education, curriculum and program development, multicultural education.

3. Képzési terület: bölcsészettudomány

4. A mesterképzésbe történö belépésnél elözményként elfogadott szakok:

4.1. Teljes kreditérték beszámításával vehetők figyelembe: pedagógia, konduktor, tanító, óvodapedagógus, gyógypedagógus alapképzési szakok.

4.2. A bemenethez a 11. pontban meghatározott feltétellel számításba vehető alapképzési szakok: andragógia, pszichológia, szociálpedagógia.

5. A képzési idö félévekben: 4 félév

6. A mesterfokozat megszerzéséhez összegyüjtendö kreditek száma: 120 kredit

6.1. Az alapozó ismeretekhez rendelhető kreditek száma: 18-22 kredit;

6.2. A szakmai törzsanyaghoz rendelhető kreditek száma: 26-30 kredit;

6.3. A differenciált szakmai anyaghoz (szakirányokhoz) rendelhető kreditek száma: 40-44 kredit;

6.4. A szabadon választható tantárgyakhoz rendelhető kreditek minimális értéke: 10 kredit;

6.5. A diplomamunkához rendelt kreditérték: 20 kredit;

6.6. A gyakorlati ismeretek aránya: törzsképzésben $40 \%$, szakirányban legalább $40 \%$. 
7. A mesterképzési szak képzési célja, az elsajátítandó szakmai kompetenciák:

A képzés célja olyan szakemberek képzése, akik megszerzett ismereteik birtokában megfelelő tudással rendelkeznek a neveléstudomány művelése és alkalmazása területén. Képesek a közoktatásban és a felsőoktatásban, illetve az oktatásügyben kutatói és/vagy alkalmazói feladatokat ellátni, részt vállalni a rendszerszintủ müködtetés feladataiból, a kutatás és a fejlesztés terén feladatokat végezni, hazai és nemzetközi szakmai fórumokon a nevelésügy hazai eredményeit kommunikálni. Megfelelő ismeretekkel rendelkeznek tanulmányaik doktori képzés keretében történő folytatásához.

a) A mesterképzési szakon végzettek ismerik: a neveléstudomány, ezen belül a neveléstörténet, a nevelésfilozófia, a nevelés- és oktatáslélektan, a neveléselmélet, az oktatáselmélet, a nevelésszociológia, az oktatásügyi komparatisztika, a kutatásmódszertan szaktudományos és alkalmazói ismereteit;

továbbá

a kora gyermekkor pedagógiája szakirányon végzettek:

- a kora gyermekkori fejlődés biológiai és pszichológiai alapjait,

- a kora gyermekkori nevelés intézményi hátterét,

- a kora gyermekkor nevelési kérdéseit,

- a kora gyermekkori nevelés módszertani sajátosságait,

- a kora gyermekkor pedagógiai kutatásait;

a családpedagógia szakirányon végzettek:

- a szülői szerep és a gyermekvállalás evolúciós és történeti hátterét,

- a családi élet különböző formáit, azok antropológiai és szociológiai kontextusát,

- a család lehetséges funkcióit, működését, a családi kommunikáció és a család életciklusait,

- a családi élet mai jellegzetességeit, fejlődésirányait és a jellegzetes családi konfliktusokat,

- az értékorientációs tendenciákat a mai magyar családokban,

- a diszfunkcionálisan müködő családtípust,

- a nem a saját családban nevelés és nevelkedés jellegzetességeit,

- a családjogi ismeretanyagot és a családgondozás szociálpolitikáját,

- a családi élet segítése, a családi konfliktusmegoldás gyakorlatának alternatíváit,

- a család és az oktatási-nevelési, valamint a családokat segitő intézmények kapcsolatát;

az elméleti és történeti kutatások szakirányokon végzettek:

- az elméleti és pedagógiatörténeti kutatási metodológiát: a kvalitatív kutatások, a narratív megközelítés különböző formáit, az összehasonlító elemzéseket és a forráselemzés különböző változatait,

- a neveléstudomány elméleti és történeti kérdéseivel határos tudományterületeket: ismeretelmélet, történeti és pedagógiai antropológia, történeti szociológia, társadalomtörténet, narratív pszichológia, 
- a könyvtári és a levéltári kutatás gyakorlatát,

- a tudományos kommunikáció és szövegalkotás kérdéseit;

a felsőoktatás-pedagógia szakirányon végzettek:

- a hazai és a nemzetközi felsőoktatási modelleket,

- a felső- és felnőttoktatásban résztvevők tanulási sajátosságait,

- a felső- és felnőttoktatásban az adekvát tanulási környezet jellemzőit, fejlesztési és értékelési lehetőségeit, a felsőoktatás terén folytatható pedagógiai kutatások specifikumait,

- felsőoktatási projektek tervezésének, szervezésének, irányításának, lebonyolításának elméletét és gyakorlatát;

a gyermek- és ifjúsági tanulmányok szakirányon végzettek:

- a gyermekfelfogás történeti változásait,

- a gyermekek mindennapi életének alakulását a különböző történeti korokban,

- a gyermek- és ifjúságpolitika kérdéskörét,

- a gyermekkor különböző szociológiai megközelítéseit,

- a tömegkommunikáció hatását a felnövekvő nemzedékekre,

- a gyermeki jogok kérdéseit,

- a gyermek- és ifjúsági szabadidős programok tervezésének és a fiatal korosztály szabadidős foglalkoztatásának módszertanát,

- a gyermek- és ifjúkor körében végzendő kutatási megközelítéseket;

az intézményfejlesztés szakirányon végzettek:

- az iskolaelméleteket,

- az európai és a magyar iskolarendszer helyzetét és problémáit,

- az iskola antropológiáját,

- a reform- és alternatív pedagógiákat,

- az iskolafejlesztés elméleti és gyakorlati problémáit,

- a fejlesztési irányzatokat,

- az iskolák sajátosságaiból kiinduló, a helyi igényekhez és szükségletekhez igazodó innováció megtervezésének, irányításának és segítésének technikáit,

- az iskolafejlesztési koncepciók, folyamatok értékelésének módszereit,

- az iskolafejlesztési projektek szervezésének, irányításának és lebonyolításának folyamatait,

- az innováció szakmai, etikai kérdéseit;

a mérés és értékelés szakirányon végzettek:

- a kutatásmódszertani és pszichológiai alapokat,

- a mérés, tesztelés, tesztfejlesztés statisztikai alapjait,

- a pedagógiai mérések, az adatgyüjtés, az elemzés, az interpretáció szabályait,

- az értékelés pszichológiai hátterét,

- a mérés-értékelés funkcióit, modelljeit és formáit,

- a mérés, tesztelés módszereit és eszközeit, 
- a legfontosabb nemzetközi és hazai mérések (IEA, PISA, MONITOR stb.) módszertanát, eredményeit,

- a vizsgáztatás, a vizsgarendszerek európai és Európán kívüli modelljeit, a hazai tapasztalatok elemzési anyagát;

a nevelési és oktatási kutatások szakirányon végzettek:

- a neveléstudomány tudományos környezetét,

- a tudományos kutatás tudományfilozófiai hátterét,

- az innovációs célú intézményi, országos és nemzetközi rendszerszintủ kutatások eredményeit,

- a nevelési és oktatási kutatások kutatásmetodológiáját,

- a nevelési és oktatási kutatásokat,

- az alkalmazott és akciókutatások folyamatainak problémaközpontú tervezési módszerét,

- a kutatásmenedzsmentre vonatkozó ismeretanyagot;

a multikulturális nevelés szakirányon végzettek:

- a többkultúrájú társadalmak kialakulásának történetét és különböző modelljeit,

- a multikulturális társadalmak szerkezetének összefüggéseit az oktatással-neveléssel,

- a migrációval kapcsolatos regionális összefüggéseket,

- a szegregáció kialakulását,

- az érdekartikuláció és érdekérvényesítés lehetőségeit az őshonosok és bevándorlók között, a társadalmi jelenségek gazdasági, munkaerőpiaci összefüggéseit az iskolázás, szakképzés szempontjából,

- a multikulturális nevelés történeti és mai lehetőségeit, formáit, az inkluzív nevelésben hatékonynak mutatkozó oktatási-nevelési metódusok elméletét és gyakorlatát;

a segítő-fejlesztő pedagógia szakirányon végzettek:

- az egyéni tanulói igényekhez való alkalmazkodás alakulását a tömegoktatás történetében, a tehetséges tanulókkal való foglalkozás történetét,

- történeti és összehasonlító pedagógiai szempontból a hazai és külföldi megoldásokat,

- a segítés-fejlesztés ,jó gyakorlatának" a példáit,

- az esélyegyenlőtlenség megjelenési formáit az iskolarendszer és az iskolai nevelésoktatás szintjén és az esélyegyenlőség-esélyegyenlőtlenség problematikáját a jogi szabályozásban,

- a különböző teljesítményzavarok és a tehetség pedagógiai diagnosztikáját,

- a teljesítményzavarok prevencióját, korrekcióját,

- a tehetségfejlesztés elméleti kérdéseit, gyakorlati lehetőségeit és problémáit;

a tanterv- és programfejlesztés szakirányon végzettek:

- a tartalmi szabályozás rendszerét, müködését, az oktatási rendszerben betöltött szerepét,

- az egyetemes és a magyar tantervtörténet legfontosabb tantervi paradigmáit és a tantervtípusokat, 
- a tantervelméleti és az alkalmazott kutatások eredményeit,

- a tantervértékelési paradigmákat, módszereket és a tantervfejlesztő munka elméleti alapjait,

- a pedagógiai programok, helyi tantervek, tantárgyi programok elemzését, értékelését, illetve projektmunka keretében történő fejlesztését,

- a tanítás és tanulás elméleti modelljeinek alkalmazási lehetőségeit, a tananyagok és taneszközök, oktatási segédanyagok elemzésének, értékelésének módszereit,

- képességfejlesztö tantárgyi programok, taneszközök, oktatási segédanyagok fejlesztését,

- a kompetencia-alapú fejlesztésre irányuló külföldi és hazai törekvéseket,

- a tananyag- és tankönyvelemzés elméletét és gyakorlatát.

b) A mesterképzési szakon végzettek alkalmasak:

- a nevelés- és oktatásügyben, a köz- és felsőoktatásban kutatói és/vagy alkalmazói feladatok ellátására,

- pedagógiai rendszerek fejlesztésében, müködtetésében és irányításában való részvételre,

- a szakterületre vonatkozó magyar és idegen nyelvü információ feltárására és elemzésére, a nevelés- és oktatásügy eredményeinek hazai és nemzetközi fórumokon való kommunikálására, jó szövegalkotásra,

- önálló tanulással meglevő képességeik fejlesztésére és új kompetenciák kialakitására;

továbbá

a kora gyermekkor pedagógiája szakirányon végzettek:

- az intézmények nevelési stratégiájának pedagógiai megalapozására,

- a nevelés szervezeti kereteinek és pedagógiai kultúrájának fejlesztésére,

- a plurális társadalom igényeiből fakadó sajátos nevelési feladatok megfogalmazására,

- szakértőként megoldásukban való aktív részvételre, a pedagógusok munkájának támogatására,

- közremüködésre egyes gyermekek és gyermekcsoportok fejlesztésére-nevelésére vonatkozó programok kialakításában, megvalósításában,

- kora gyermekkori pedagógiai kutatások végzésére;

a családpedagógia szakirányon végzettek:

- nevelési-oktatási intézményekben, a családokat segítő intézményrendszerben szakszerủ támogatás nyújtására az erre aktuálisan vagy folyamatosan rászoruló családoknak,

- szakértő részvételre kutatásokban;

az elméleti és történeti kutatások szakirányokon végzettek:

- pedagógiatörténeti és pedagógiaelméleti kutatások végzésére, elméleti és történeti kutatások tervezésére, támogatására, értékelésére és tudományos fórumokon történő kommunikálására, 
- az elméleti és történeti kutatásokkal foglalkozó hallgatók munkájának segítésére, tanácsadásra;

a felsőoktatás-pedagógia szakirányon végzettek:

- felsőoktatási fejlesztések tervezésére, támogatására, értékelésére,

- szakértőként részt venni a felsőoktatási menedzsment munkájában,

- felsőoktatás-pedagógiai kutatások végzésére;

a gyermek- és ifjúsági tanulmányok szakirányon végzettek:

- ifjúságsegítő szolgálatokban való fejlesztő közremüködésre,

- a tanórán kívüli nevelés tartalmi és szervezeti kereteinek tervezésére, e nevelési alkalmak szakszerü vezetésére, pedagógiai irányítására,

- szakértő részvételre gyermek- és ifjúságsegítő kutatásokban;

az intézményfejlesztés szakirányon végzettek:

- a pedagógiai intézményfejlesztés elméleti kérdéseiben tudásuk továbbfejlesztésére és alkalmazására az iskolai innovációkban a helyi társadalmi igényeinek, elvárásainak megfelelően;

a mérés és értékelés szakirányon végzettek:

- a tanulók, tanulóközösségek, nevelési-oktatási intézmények, illetve az oktatási rendszer értékelését szolgáló mérések lebonyolítására, ilyen célú mérőeszközök fejlesztésére;

a nevelési és oktatási kutatások szakirányon végzettek:

- a nevelés-oktatás különböző szintjein megjelenő pedagógiai problematika felismerésére,

- fejlesztő jellegü nevelési-oktatási kutatások megtervezésére, végzésére;

a segítő-fejlesztő pedagógia szakirányon végzettek:

- általános tanulástechnikai fejlesztésre és tanácsadásra,

- az eltérő bánásmódot igénylő tanulók szakszerü segítésére;

a multikulturális nevelés szakirányon végzettek:

- eltérő kultúrájú fiatalok együttmüködésének megszervezésére, irányítására,

- a felmerült konfliktusok értelmezésére, kezelésére, hatékony kommunikáció elősegítésére;

a tanterv- és programfejlesztés szakirányon végzettek:

- a központi tantervekhez igazodó helyi tantervek, tantárgyi programok, fejlesztő programok kidolgozására.

c) A szakképzettség gyakorlásához szükséges személyes adottságok és készségek:

- önálló munkavégzésre való képesség,

- kreativitás,

- jó problémamegoldó képesség,

- döntéshozatali képesség, 
- jó együttmüködési készség,

- a közösségbe történő beilleszkedés képessége és igénye,

- saját tevékenység kritikus értékelésének és irányításának a képessége,

- önszabályozás, az önfejlesztés igénye,

- értékek kialakítására és megtartására törekvő magatartás.

\section{A mesterfokozat és a szakképzettség szempontjából meghatározó ismeretkörök:}

8.1. Az alapképzésben megszerzett ismereteket tovább bővítő, mesterfokozathoz szükséges alapozó ismeretkörök (18-22 kredit): neveléstörténeti tanulmányok, kutatások (nevelésfilozófiák és elméletek története), elméleti pedagógia (a neveléstudomány szaknyelve), nevelés- és oktatáslélektan (kognitív pszichológia, neveléslélektan), oktatástudomány (tanítás- és tanuláselméletek), a nevelésszociológia alkalmazásai (a nevelésszociológiai információ), oktatásügyi komparatisztika (világgazdasági változások és az oktatás).

8.2. A szakmai törzsanyag kötelező ismeretkörei (26-30 kredit): neveléstörténeti tanulmányok, kutatások (pedagógiai problématörténet, történeti antropológia), elméleti pedagógia (neveléselmélet - pedagógiai antropológia, neveléstudományi modellek és paradigmák), nevelés- és oktatáslélektan (pedagógiai szociálpszichológia), oktatástudomány (tantervelméletek, képességek fejlődése és fejlesztése), a nevelésszociológia alkalmazásai (iskolaszociológiai szemléletek és szakirodalom, kutatások a nevelésszociológiában), oktatásügyi komparatisztika (oktatási rendszerek az EU-ban, oktatásstatisztikai elemzések).

8.3. A szakmai törzsanyag kötelezően választható ismeretkörei:

differenciált szakmai ismeretek: 40-44 kredit

szakirányok ismeretkörei;

diplomamunka: 20 kredit.

\section{A képzéshez kapcsolt szakmai gyakorlat követelményei:}

A szakmai gyakorlat a köz- és a felsőoktatás különböző színterein, intézményeiben végzett terepmunka, amelynek időtartamát a szakirányokhoz kapcsolódóan a szakot indító felsőoktatási intézmény határozza meg.

\section{Idegennyelv-ismeret követelményei:}

A mesterfokozat megszerzéséhez egy államilag elismert középfokú C típusú nyelvvizsga vagy azzal egyenértékủ érettségi bizonyítvány, illetve oklevél szükséges.

\section{A mesterképzésbe való felvétel feltételei:}

A mesterképzésbe való felvétel feltétele, hogy a hallgatónak a kredit megállapításának alapjául szolgáló ismeretek - felsőoktatási törvényben meghatározott - összevetése alapján elismerhetö legyen legalább 15 kredit az alábbi ismeretkörökben: neveléstörténet, neveléspszichológia, kutatásmódszertan, informatika és számítógép-használat, nevelési-segítőszolgálati terepgyakorlat. 